\title{
Floristic diversity and conservation value of the biodiversity refuge area of the Soubré hydroelectric dam (South-West of Côte d'Ivoire)
}

\author{
Yao Jean-Clovis KOUADIO ${ }^{1 *}$, Abdoulaye CISSÉ ${ }^{1}$, Kouassi Bruno KPANGUI ${ }^{2}$, \\ Marie-Solange TIÉBRÉ ${ }^{1,3}$, Djakalia OUATTARA ${ }^{1,3}$ and Kouakou Edouard N'GUESSAN ${ }^{1}$ \\ ${ }^{1}$ Félix Houphouët-Boigny University, UFR Biosciences, Botanical Laboratory, 22 PB 582 Abidjan 22, \\ Côte d'Ivoire. \\ ${ }^{2}$ Jean Lorougnon Guédé University, UFR Environment, PB 150 Daloa, Côte d'Ivoire. \\ ${ }^{3}$ National Floristic Center, Félix Houphouët-Boigny University, 22 PB 582 Abidjan 22, Côte d'Ivoire. \\ *Corresponding author ; E-mail: kouadio.clovis1@ufhb.edu.ci; jeanclovis08@gmail.com;
} Tel: +2250708050892

\begin{tabular}{ccc}
\hline Received: 03-03-2021 & Accepted: 20-08-2021 & Published: 31-08-2021 \\
\hline
\end{tabular}

\begin{abstract}
After the establishment of the biodiversity conservation area of the Soubre hydroelectric dam, scientific studies showing its value as a biodiversity reserve and its importance for the population were not implemented. As a result, no sustainable management strategy has been initiated. this study was conducted to make up for this shortcoming. It aims to assess its conservation value. The data collection methodology combined botanical inventories and an ethnobotanical survey. The analyse of data was based on the plant diversity and the importance of the area for local populations. Investigations show a rich flora of 346 species. There are 38 endemic species, 10 vulnerable and 8 locally threatened with extinction. This flora richness allows to attribute to the conservation area the High Conservation Value of category 1 (HCV 1). Among the species list, 84 are cited by the populations as useful plants. The use categories are, in order of importance, medicinal use, food use, Handicrafted use, timber. The organs sought are mainly the leaves in the practice of traditional medicine, the fruits in food and the stem in crafts, timber and firewood. Among useful species, 13 are very important for local population. Of these, 6 are less abundant in the area such as Ricinodendron heudelotii, Carpolobia lutea G. Don. The capacity for the area to serve as a refuge for useful species gives it the HCV 5. These results will allow the implementation of appropriate management.
\end{abstract}

(C) 2021 International Formulae Group. All rights reserved.

Keywords: Ecological compensation, useful plant, importance value.

\section{INTRODUCTION}

Throughout the world, the appropriate management of biodiversity ensures the wellbeing of populations. Indeed, ecosystems provide many services including provisioning, regulating and socio-cultural services (MEA,
2005). Unfortunately, economic development leads to the overexploitation of resources, which in turn leads to habitat fragility, species extinction, pollution and global warming. All these factors irremediably deplete natural resources, whose renewal process is relatively 
slow (Schneiders, 2012). The increasing pressures on natural resources in the context of economic development are diverse.

In Côte d'Ivoire, the causes of natural resource degradation are numerous (Aké-Assi, 2001; Aké-Assi, 2002; Adou Yao and N'Guessan, 2005; Vroh, 2013). The first is agriculture with the rise of monocultures (Konan, 2008). After independence, the country structured its growth around monocultures. To achieve this objective, huge plantations of cash crops such as coffee, cocoa, oil palm, rubber, etc., were created. While agriculture has enabled Côte d'Ivoire to benefit from strong economic growth (8.5\% growth in 2016), its development has been at the expense of forest cover. Secondly, there are development projects such as the building of roads, the exploitation of mining resources, the construction of hydroelectric dams which nevertheless remain a factor of advanced degradation of the flora in Côte d'Ivoire.

From 1960 to nowadays, the forest area has increased from 16 million hectares (Lanly, 1969) to 3.4 million hectares in 2015 (FAOREDD+, 2016). To remedy this loss of biodiversity, the State of Côte d'Ivoire, on the one hand, encourages farmers to practice agroforestry and, on the other hand, communities to create voluntary nature reserves, and companies to develop strategies and policies towards biodiversity conservation. One of the most recommended recent strategies is ecological compensation through the creation of a biodiversity refuge area. Thus, during the implementation of the Soubré hydroelectric dam construction project on the Cavally River by the promoter CI-ENERGIE, a 200 ha area was dedicated to biodiversity conservation. The development and restoration of the area has required the revegetation, assisted regeneration and protection of the formerly cultivated areas in order to create a new area rich in biodiversity. However, after this development and restoration phase, what is the evolution of the ecological values? This information is necessary for a better management and planning of the conservation of this natural resource. In this sense, the concept of High Conservation Values (HCV) appears to be a useful approach that will allow appropriate management decisions to be taken to ensure the preservation and/or enhancement of a HCV. It is within this framework that this study was conducted. Its objective was to assess the conservation value of the biodiversity conservation area based specifically on its plant diversity and its importance for local populations.

\section{MATERIALS AND METHODS \\ Study area}

The biodiversity conservation area is located in the Nawa region, of which the town of Soubré is the regional capital. It was set up following the building of the Soubré hydroelectric dam to compensate the biodiversity loss. It is located immediately downstream of the hydroelectric dam and constitutes an ecological continuum of 200 ha spread over the left and right banks of the Sassandra River (Figure 1).

\section{Method of data collection}

Flower inventory: Two field survey techniques were used. These are the surface survey and the roving survey. These two types of surveys are complementary. The surface survey consisted of the delimitation of plots of $20 \mathrm{~m}$ x $20 \mathrm{~m}$ (400 $\mathrm{m}^{2}$ ) each in the different types of biotopes encountered. Within each plot, firstly, we identify the type of vegetation. Then, all the plant species encountered are identified and their names noted on the survey form bearing the plot number. For each individual, the circumference is measured and noted when it reaches at least $15.70 \mathrm{~cm}$. This corresponds to a Diameter at Breast Height (DBH) of $5 \mathrm{~cm}$. The geographical coordinates of the plot are recorded using a GPS. 
The roving surveys only concerned species not encountered in the surface surveys. The species observed in this second type of inventory are noted to complete the general floristic list.

Ethnobotanical survey on the availability of useful plants: An ethnobotanical survey was carried out among the populations living next to the biodiversity conservation area. It focused on the identification of plants used by local population. The persons identified to carry out this study were traditional medicine practitioners and people with local knowledge of plants. A quiz specific to ethnobotanical surveys was used as a benchmark. For each species, the questions concerned the uses and organs used. The list of plants obtained in the different fields of use (food, medicinal, artisanal, socio-cultural, etc.) was compared with the floristic list of the area in order to detect the availability of these species. This aspect of the work is all the more important as it makes it possible to know whether the conservation area allows the services provided by the surrounding plant biodiversity to be restored prior to the project.

\section{Data analysis methodology}

Richness and floristic composition: The number of species inventoried for the different types of vegetation has been determined. For each of the inventoried species, we noted the family, genus, biological types and phytogeographic distribution. Subsequently, we evaluated the floristic richness. This, led us to cross-reference the floristic list, firstly, with the list of utilitarian species of the region obtained from the ethnobotanical survey, secondly, with the red list of IUCN (2018) and the list of rare and endangered species of AkéAssi (1998), and lastly, with the list of endemic species established from the work of Aké-Assi (2001; 2002) and Poorter (2004).
Vegetation structure of the different biotopes: The vegetation structure in the different biotopes was assessed from the distribution of individuals by diameter class often referred to as "total structure" by foresters (Bouko et al., 2007). This makes it possible to account for the demographic structure of woody stands through histograms of the distribution of individuals according to diameter classes.

Species importance value: The species importance value (IVsp) represents the ratio between the number of different uses for the species (iv) and the number of different uses for all listed species (Liv). It is calculated according to the following formula:

$I V s p=\frac{i v}{\sum i v} \times 100$

This value makes it possible to highlight the species that are in demand in several fields and which would therefore be over-exploited.

Assessment of species availability: This was assessed on the basis of the species rarity index. This index is calculated using the following formula (Géhu and Géhu, 1980).

$R i=1-\frac{n i}{N i} \times 100$

In this equation $R i$ represents the rarefaction index of a species $\mathrm{i}$; $n i$ the number of plots where it is encountered and $\mathrm{N}$ the total number of plots inventoried.

Species with a rarefaction index of less than $80 \%$ are considered preferential, very frequent and abundant in the areas studied. Those whose rarefaction indices are higher than $80 \%$ are said to be rare and therefore highly endangered in the locality.

Statistical analysis of the data: A Correspondence Analysis (CA) was carried out in order to reveal the existence of an interaction between the categories of use and the organs used. The statistical software $\mathrm{R}$ version 4.0.0 was used for this test. 


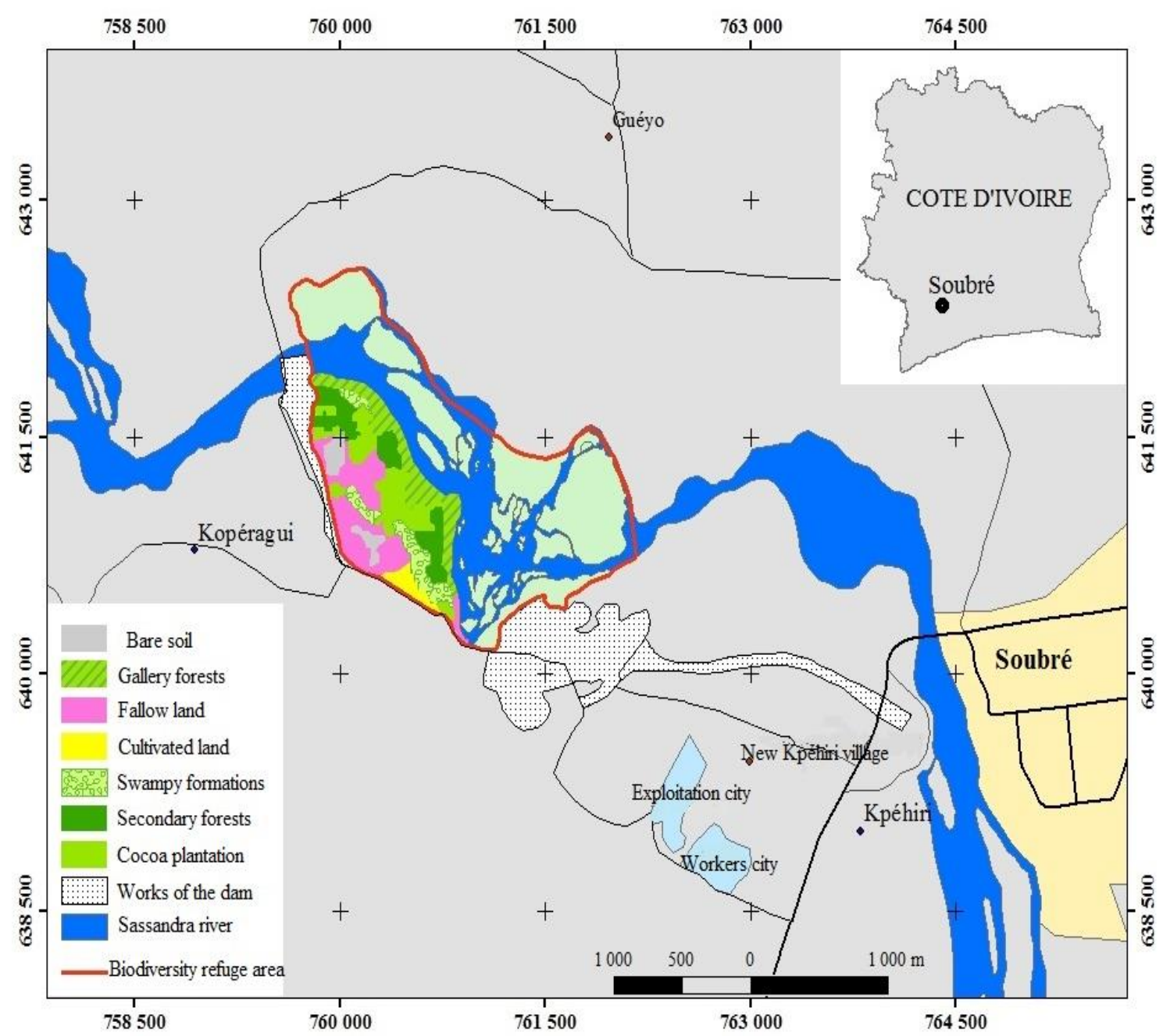

Figure 1: Map showing the location of biodiversity conservation area.

\section{RESULTS}

\section{Types of habitat encountered}

The main types of habitats encountered in the biodiversity conservation area are: gallery forests, secondary forests, swampy formations, fallow land and formerly cultivated areas.

Gallery forests: These are forest formations that border the different tributaries of the river Sassandra. Their floristic composition is often quite particular. Depending on their level of conservation, characteristic species such as Uapaca heudelotii, Uapaca guineensis, Macaranga spp, Alchornea cordifolia, Uapaca heudelotii, Napoleaona vogelii and Pterocarpus santaloides can be found.

Secondary forests : These are plant formations that result from the anthropisation of forests as a result of various human activities (forest exploitation, cutting of wood and shrubs for traditional use, cultivation). They are found between cocoa plantations and in the background of gallery forest. They are forests with a canopy that is open to varying degrees with a dense undergrowth. In the upper stratum of these formations, species such as Ceiba pentandra and Piptadeniastrum africanum are found. The secondary stratum is represented by 
heliophilic species such as Musanga cecropioides, Ficus exasperata, Sterculia tragacantha. The last is represented by herbaceous and other species such as Chromolaena odorata, Solanum rugosum, Trema orientalis.

Swampy formations : These types of plant formations are found in lowland areas on hydromorphic soils. The soils are less permeable to water due to the presence of large quantities of clay. Some of these plant formations can be described as Raphia forests due to the abundance of individuals of this species. They present a good level of conservation because human activities are rare there, apart from the removal of raffia branches. The most frequent species in the upper stratum are: Raffia hookeri, Hallea ledermanii and Uapaca guineensis. The lower stratum is dominated by Alchornea cordifolia, Palisota hirsuta, Nephrolepis bisserrata, and rattans such as Laccospermum secundiflorum and Calamus deeratus. In other reconstituted formations, species such as Pueraria phaseoloides, Cyclosorus dentatus, Alchornea cordifolia, Chromolaena odorata, Palisota hirsuta are frequently encountered.

Fallow land : Fallow land is very common in the project area. There are many heliophilic species such as Chromolaena odorata, Ficus spp, Solanum rugosum, Trema orientalis, Musanga cecropioides, Centrosema pubescens, Sida acuta, Cynodon dactylon. Some large trees such as Albizia adianthifolia are found. The lianas are represented by Griffonia simplicifolia, Centrosema pubescens, Indigofera macrophylla.

Formerly cultivated areas: The are two types of crops abandoned for the project. These are rubber and cocoa plantations. The cocoa plantations can be described as simple agroforests. Their canopy is open and many plant species are found that were spared during the establishment of the plantation. These are Ricinodendron heudelotii, Elaeis guineensis, Citrus spp. Distemonanthus benthamianus, Ceiba pentandra, Bombax buonopozense, Citrus sinensis, Citrus reticulata, Persea americana. There is also a recovery of vegetation with an abundance of young shoots of species such as Antiaris africana, Milicia excelsa, Pycnanthus angolensis, etc. As for rubber tree plantations, very few species can be found there. These are mainly Tetrapleura tetraptera and Albizia adianthifolia.

\section{Diversity of the conservation area}

Flora richness and composition : The study of the flora has enabled 346 plant species to be identified. They are divided into 262 genera and 92 families. The families with the highest number of species are the Fabaceae (25 species), Rubiaceae (22 species), Euphorbiaceae (19 species), Poaceae (17 species) and Moraceae (15 species). Twentyseven (27) families out of the 90 (i.e. 30\%) include at least 4 species each. They alone contain $72.47 \%$ of the plant species recorded. The dominance of families varies according to the different biotopes. For example, in fallow land and abandoned cocoa and rubber plantations, the dominance of Euphorbiaceae can be noted. The Rubiaceae dominate in secondary forests, while the Fabaceae and Poaceae dominate in gallery forests and swampy areas respectively.

A total of 12 biological types have been identified on the biodiversity conservation area. These are: megaphanerophytes, mesophanerophytes, microphanerophytes, nanophanerophytes, chamephytes, therophytes, hemicryptophytes, geophytes, rhizomatous geophytes, hydrophytes and pyrophytic hemicryptophytes. The microphanerophyte $(\mathrm{mp})$ species are the most numerous. They are represented by 158 species, i.e. $45.40 \%$ of the species.

The phytogeographic distribution shows that the whole conservation area is dominated by species found in the GuineanCongolese region (GC). These species represent $58.04 \%$ of all species sampled. They are followed by GC-SZ species (transition species between the Guineo-Congolese Regions and species endemic to the SudanoZambezian Region).

Species with special status : Of the 346 species recorded in the biodiversity conservation area, 
50 species have a conservation status (endemic species and rare and endangered species), i.e. $14.36 \%$ of the diversity (Table 1). It is estimated that 38 species are endemic. Of these, 5 are endemic to Côte d'Ivoire (GCi). These include Baphia bancoensis Aubrév (Fabaceae), Leptoderris miegei Aké Assi \& Mangenot (Fabaceae), Eugenia miegeana Aké Assi (Myrtaceae). There are 28 endemic species to the Upper Guinea (HG) area. These include Baissea zygodioides (K. Schum.) Stapf (Apocynaceae), Copaifera salikounda Heckel (Caesalpiniaceae), Diospyros heudelotii Hiern (Ebenaceae). This group of species is most abundant in gallery and secondary forests. Twenty-seven endemic species belonging to the West African forest block (GCW) have been recorded. As an example, we can cite Rinorea subintegrifolia (P. Beauv.) O. Ktze and Tiliacora dinklagei Engl. There are 10 endangered species on the IUCN Red List of Threatened Species (IUCN, 2018). all of which are considered vulnerable. Among them are Albizia ferruginea (Guill. \& Perr.) Benth. (Mimosaceae), Copaifera salikounda Heckel, Craibia atlantica Dunn, Entandrophragma angolense (Welw.) C. DC., Entandrophragma cylindricum (Sprague) Srague, Nesogordonia papaverifera (A. Chev.) R. Capuron, Milicia regia (Welw.) Berg. (Moraceae). At the national level, 8 species are considered rare and endangered according to Aké-Assi (1998). These include Garcinia afzelii Engl (Clusiaceae), Maranthes robusta (Oliv.) France (Chrysobalanaceae), Pararistolochia mannii (Hook.f.) Keay (Aristolochiaceae), Milicia excelsa (Welw.) Berg.

\section{Distribution of stems by diameter class}

The horizontal structure of the different types of biotopes encountered presents variable shapes (Figure 2). Within all the biotopes sampled, stems with small diameters (5 to 10 $\mathrm{cm})$ are the most numerous except in the secondary forest. They account for more than a third of all the stems. Next, come stems with diameters between 10 and $20 \mathrm{~cm}$. The proportions of stems with a diameter greater than $20 \mathrm{~cm}$ are low. In the swampy formation, individuals with a diameter greater than $10 \mathrm{~cm}$ are absent. Thus, in all of the biotopes, a regression from the smallest to the largest diameters can be observed. This gives the curves obtained an inverted "J" shape.

\section{Categories of plant use cited by the populations}

The different categories of plant use cited for the species are, in order of importance, medicinal use (71 species), food use (28 species), handicrafted use (20 species) and timber, which concerns 14 species (Figure 3). Various other uses such as ornament, fodder, insecticide, fishing and hunting accessories, packaging are also mentioned and concern 11 species.

\section{Plant organs used}

Different plant organs are used by the populations. Leaves are the most used. They have been mentioned 58 times in the different plant uses. Then, come the stems, the bark and the fruit. The frequencies of citations of the latter are respectively 45; 35 and 22 (Figure 4).

There is a significant link $\left(\chi^{2}=260.49\right.$; $P<0.001)$ between the categories of plant use and the organs used. Visualisation of the nature of the link through Correspondence Analysis (CA) indicates that the first two axes account for $96.59 \%$ of this gap at independence (Figure 5). Axis 1 contrasts a first group of uses, which are the uses of wood energy plants, in handicrafted use and timber, with food and medicinal uses. Thus, in this first group of uses, it is the stems that are used. Axis 2 highlights two other groups, including food use on the one hand and medicinal use on the other. In terms of medicinal use, it is the leaves that are mainly used. They are followed by the bark and the root. As far as food use is concerned, the organs used are, in order of importance, fruits, seeds, rhizomes, buds, flowers and tubers.

\section{Importance value of species}

The most important species for the populations are thirteen (13). Their importance values vary from 50 to $66.67 \%$ (Table 2). These species are used in at least three (3) use 
categories. We have Ricinodendron heudelotii (Baill.) Pierre ex Heckel, Elaeis guineensis Jacq, Theobroma cacao Linn, Ceiba pentandra (L.) Gaertn, Spondias mombin L, Napoleonaea vogelii Hook. \& Planch. Nesogordonia papaverifera (A. Chev.) Cap., Pycnanthus angolensis (Welw.) Warb., Carpolobia lutea G. Don, Celtis zenkeri Engl., Carica papaya L. var. papaya, Entandrophragma angolense (Welw.) C. DC, Bombax buonopozense P. Beauv.

Table 1: List of species with special status.
Availability of useful plants in the conservation area

Among the important species, six (6) such as Ricinodendron heudelotii, Carpolobia lutea G. Don are less abundant in the biodiversity conservation area, which is reflected in their scarcity index above $80 \%$ (Table 2). The most abundant are among others Elaeis guineensis Jacq, Theobroma cacao Linn, Ceiba pentandra (L.) Gaertn.

\begin{tabular}{|c|c|c|c|c|c|}
\hline $\mathbf{N}^{0}$ & Species & Family & Endemism & $\begin{array}{l}\text { UICN } \\
\text { status }\end{array}$ & $\begin{array}{l}\text { Aké-Assi } \\
\text { status }\end{array}$ \\
\hline 1 & Afzelia bella var. gracilior Keay & Caesalpiniaceae & GCW & & \\
\hline 2 & Albizia ferruginea (Guill. \& Perr.) Benth. & Mimosaceae & & VU & \\
\hline 3 & Ancistrocladus barteri Sc. Elliot & Ancistrocladaceae & $\mathrm{GCW} / \mathrm{HG}$ & & \\
\hline 4 & Baissea zygodioides (K. Schum.) Stapf & Apocynaceae & HG & & \\
\hline 5 & Baphia bancoensis Aubrév. & Fabaceae & GCi & & \\
\hline 6 & $\begin{array}{l}\text { Brachystegia leonensis Burtt Davy \& } \\
\text { Hutch. }\end{array}$ & Caesalpiniaceae & GCW/HG & & \\
\hline 7 & Bussea occidentalis Hutch. & Caesalpiniaceae & $\mathrm{HG}$ & & \\
\hline 8 & Chassalia afzelii (Hiern) K. Schum. & Rubiaceae & GCW & & \\
\hline 9 & Cissus miegei Tchoumé & Vitaceae & $\mathrm{GCi} / \mathrm{HG}$ & & \\
\hline 10 & Cola caricaefolia (G. Don) K. Schum. & Sterculiaceae & GCW/HG & & \\
\hline 11 & Combretum comosum G. Don & Combretaceae & GCW & & \\
\hline 12 & Copaifera salikounda Heckel & Caesalpiniaceae & GCW/HG & VU & \\
\hline 13 & Craibia atlantica Dunn & Fabaceae & & VU & \\
\hline 14 & Croton scarciesii Sc.Elliot & Euphorbiaceae & GCW & & \\
\hline 15 & Dialium aubrevillei Pellegr. & Caesalpiniaceae & GCW/HG & & \\
\hline 16 & Dichapetalum toxicarium (G. Don) Baill. & Dichapetalaceae & HG & & \\
\hline 17 & Dictyophleba leonensis (Stapf) Pichon & Apocynaceae & GCW & & \\
\hline 18 & Diospyros heudelotii Hiern & Ebenaceae & GCW/HG & & \\
\hline 19 & $\begin{array}{l}\text { Entandrophragma angolense (Welw.) C. } \\
\text { DC. }\end{array}$ & Meliaceae & & VU & \\
\hline 20 & $\begin{array}{l}\text { Entandrophragma cylindricum (Sprague) } \\
\text { Srague }\end{array}$ & Meliaceae & & VU & \\
\hline 21 & Euadenia eminens Hook. $\mathrm{f}$ & Capparidaceae & GCW/HG & & \\
\hline 22 & Eugenia miegeana Aké Assi & Myrtaceae & GCi & & \\
\hline 23 & Garcinia afzelii Engl. & Clusiaceae & & VU & PRE \\
\hline
\end{tabular}




\begin{tabular}{|c|c|c|c|c|c|}
\hline $\mathbf{N}^{\mathbf{0}}$ & Species & Family & Endemism & $\begin{array}{l}\text { UICN } \\
\text { status }\end{array}$ & $\begin{array}{l}\text { Aké-Assi } \\
\text { status }\end{array}$ \\
\hline & Hibiscus comoensis A. Chev. ex Hutch. & & & & \\
\hline 24 & \& Dalz & Malvaceae & $\mathrm{GCi} / \mathrm{HG}$ & & PRE \\
\hline & Isolona cooperi Hutch. \& Dalz. ex & & & & \\
\hline 25 & Cooper \& Record & Annonaceae & GCW/HG & & \\
\hline 26 & $\begin{array}{l}\text { Lannea nigritana (Sc. Elliot) Keay var. } \\
\text { pubescens Keay }\end{array}$ & Anacardiaceae & & & PRE \\
\hline 27 & $\begin{array}{l}\text { Leptoderris miegei Aké Assi \& } \\
\text { Mangenot }\end{array}$ & Fabaceae & $\mathrm{GCi} / \mathrm{HG}$ & & \\
\hline 28 & Maranthes robusta (Oliv.) France & Chrysobalanaceae & & & PRE \\
\hline 29 & Milicia excelsa (Welw.) Berg & Moraceae & & & PRE \\
\hline 30 & Milicia regia A. Chev. & Moraceae & $\mathrm{GCW} / \mathrm{HG}$ & VU & PRE \\
\hline 31 & Millettia lane-poolei Dunn & Fabaceae & GCW/HG & & \\
\hline 32 & Millettia lucens (Se. Elliot) Dunn & Fabaceae & $\mathrm{GCW} / \mathrm{HG}$ & & \\
\hline & Mitragyna ledermannii (K. Krause) & & & & \\
\hline 33 & Ridsdale & Rubiaceae & & VU & \\
\hline 34 & Mussaenda chippii Wernham & Rubiaceae & $\mathrm{GCW} / \mathrm{HG}$ & & \\
\hline 35 & Myrianthus libericus Rendle & Cecropiaceae & HG & & \\
\hline & Nesogordonia papaverifera (A. Chev.) & & & & \\
\hline 36 & R. Capuron & Sterculiaceae & & VU & \\
\hline 37 & Neuropeltis prevosteoides Mangenot & Convolvulaceae & GCW/HG & & \\
\hline 38 & Pararistolochia mannii (Hook.f.) Keay & Aristolochiaceae & & & PRE \\
\hline 39 & Penianthus zenkeri (Engl.) Diels & Mennispermaceae & GCW & & \\
\hline 40 & Platysepalum hirsutum (Dunn) Hepper & Fabaceae & GCW/HG & & \\
\hline 41 & $\begin{array}{l}\text { Rinorea subintegrifolia (P. Beauv.) O. } \\
\text { Ktze. }\end{array}$ & Violaceae & GCW & & \\
\hline 42 & Salacia lateritia N. Hallé & Hippocrateaceae & HG & & \\
\hline 43 & Sherbournia calycina (G.Don) Hua & Rubiaceae & $\mathrm{GCW} / \mathrm{HG}$ & & \\
\hline 44 & Strychnos dinklagei Gilg & Loganiaceae & $\mathrm{GCW} / \mathrm{HG}$ & & \\
\hline 45 & Tiliacora dinklagei Engl. & Mennispermaceae & GCW & & \\
\hline 46 & Triclisia patens Oliv. & Mennispermaceae & GCW/HG & & \\
\hline 47 & Urera keayi Letouzey & Urticaceae & HG & & \\
\hline 48 & $\begin{array}{l}\text { Uvaria ovata (Dunal) A. DC. subsp. } \\
\text { afzeliana (DC.) Keay }\end{array}$ & Annonaceae & & & PRE \\
\hline 49 & Uvariodendron occidentalis Le Thomas & Annonaceae & $\mathrm{GCW} / \mathrm{HG}$ & VU & \\
\hline 50 & Xylia evansii Hutch. & Mimosaceae & GCW/HG & & \\
\hline
\end{tabular}




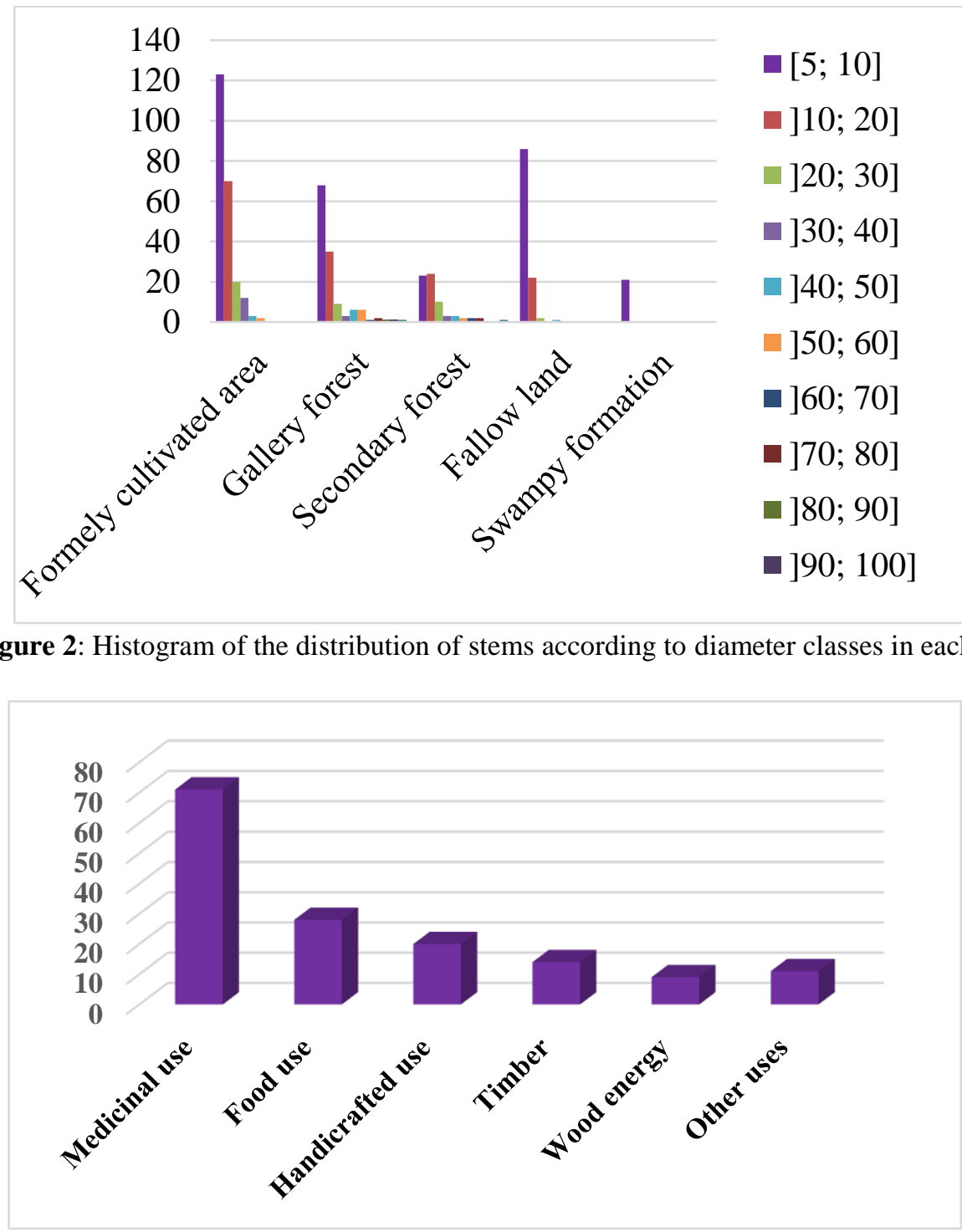

Figure 3: Species distribution by plant use category.

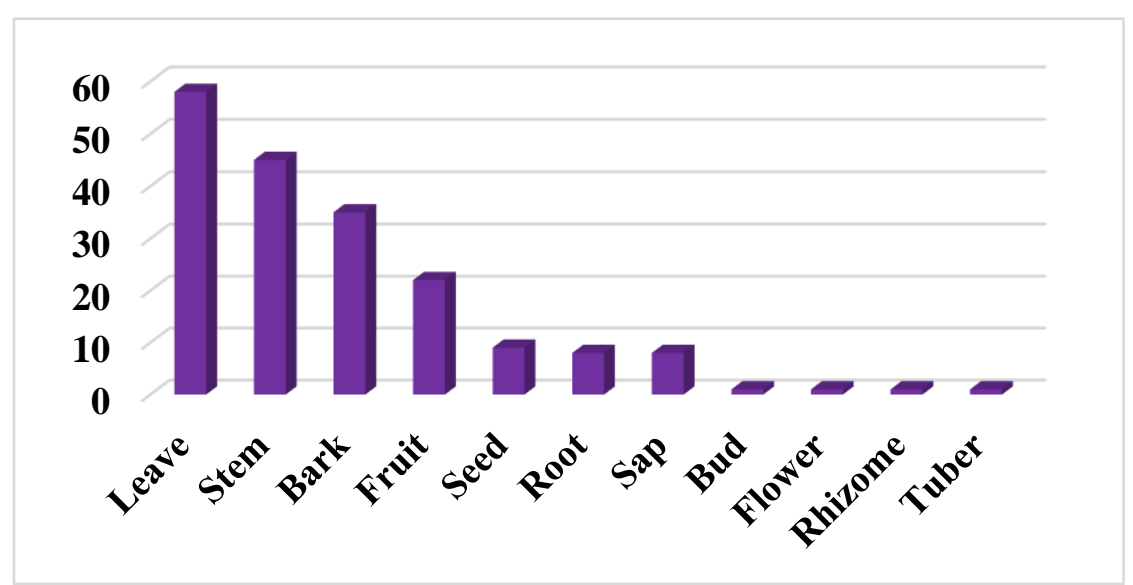

Figure 4: Frequency of Citation of Plant Organs in Use Categories. 


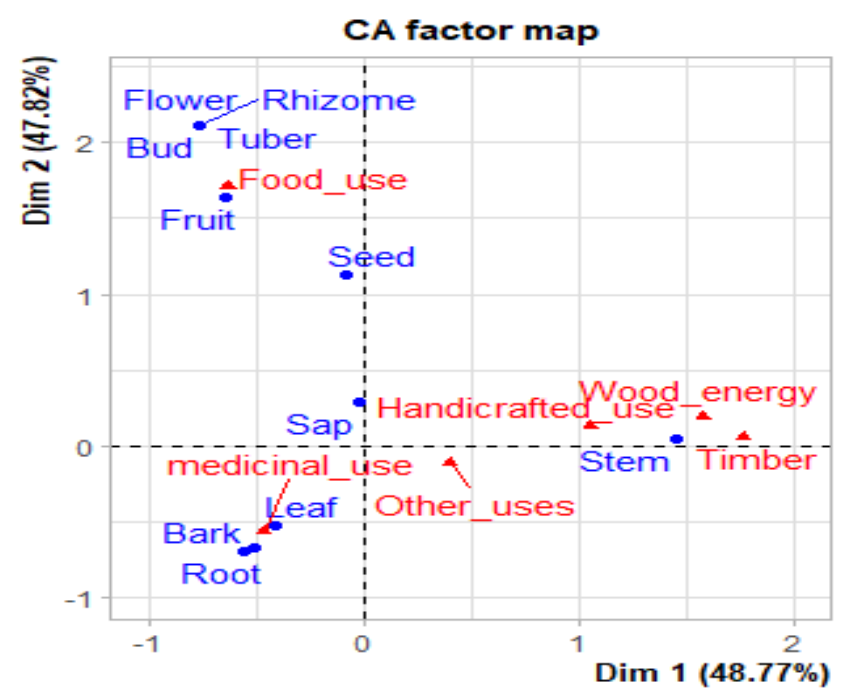

Figure 5: Factor map of use categories according to the organs used.

Table 2: Importance value and availability of some species in the biodiversity conservation area.

\begin{tabular}{|c|c|c|c|c|c|c|c|c|c|}
\hline $\mathbf{N}^{\circ}$ & Taxons & $\begin{array}{l}\text { Food } \\
\text { use }\end{array}$ & $\begin{array}{l}\text { Medicinal } \\
\text { use }\end{array}$ & $\begin{array}{l}\text { Handicrafted } \\
\text { use }\end{array}$ & Timber & $\begin{array}{l}\text { Wood } \\
\text { energy }\end{array}$ & $\begin{array}{l}\text { Other } \\
\text { uses }\end{array}$ & $\begin{array}{l}\text { Importance } \\
\text { value }\end{array}$ & $\begin{array}{l}\text { Index of } \\
\text { Rarefaction }\end{array}$ \\
\hline & $\begin{array}{l}\text { Ricinodendron } \\
\text { heudelotii (Baill.) }\end{array}$ & & & & & & & & \\
\hline \multirow[t]{2}{*}{1} & Pierre ex Heckel & 1 & 1 & 1 & & 1 & & 66,67 & 89,47 \\
\hline & Elaeis guineensis & & & & & & & & \\
\hline \multirow[t]{2}{*}{2} & Jacq. & 1 & 1 & 1 & - & - & - & 50,00 & 26,32 \\
\hline & Theobroma cacao & & & & & & & & \\
\hline \multirow[t]{2}{*}{3} & Linn. & 1 & - & - & & 1 & 1 & 50,00 & 57,89 \\
\hline & Ceiba pentandra (L.) & & & & & & & & \\
\hline 4 & Gaertn. & 1 & 1 & - & 1 & - & - & 50,00 & 68,42 \\
\hline \multirow[t]{2}{*}{5} & Spondias mombin L. & 1 & 1 & - & - & & 1 & 50,00 & 73,68 \\
\hline & Napoleonaea vogelii & & & & & & & & \\
\hline \multirow[t]{2}{*}{6} & Hook. \& Planch. & 1 & 1 & 1 & - & - & - & 50,00 & 78,95 \\
\hline & $\begin{array}{l}\text { Nesogordonia } \\
\text { papaverifera (A. }\end{array}$ & & & & & & & & \\
\hline 7 & Chev.) Cap. & & 1 & 1 & 1 & - & - & 50,00 & 78,95 \\
\hline 8 & $\begin{array}{l}\text { Pycnanthus angolensis } \\
\text { (Welw.) Warb. }\end{array}$ & - & 1 & 1 & 1 & - & - & 50,00 & 78,95 \\
\hline 9 & $\begin{array}{l}\text { Carpolobia lutea } \\
\text { G.Don }\end{array}$ & 1 & 1 & 1 & - & - & - & 50,00 & 84,21 \\
\hline 10 & Celtis zenkeri Engl. & - & 1 & - & 1 & 1 & - & 50,00 & 84,21 \\
\hline 11 & $\begin{array}{l}\text { Carica papaya L. var. } \\
\text { papaya }\end{array}$ & 1 & 1 & - & - & - & 1 & 50,00 & $\mathbf{8 9 , 4 7}$ \\
\hline 12 & $\begin{array}{l}\text { Entandrophragma } \\
\text { angolense (Welw.) C. } \\
\text { DC. }\end{array}$ & - & 1 & 1 & 1 & - & - & 50,00 & 89,47 \\
\hline & Bombax buonopozense & & & & & & & & \\
\hline 13 & P. Beauv. & 1 & 1 & - & 1 & - & - & 50,00 & 94,74 \\
\hline
\end{tabular}




\section{DISCUSSION}

The study of the flora has made it possible to identify 346 species divided into 262 genera and 92 families in the biodiversity conservation area. This floristic richness is in the same order of magnitude as the Agbaou Gold Operation ecological compensation area called the Agbaou Dekpa forest reserve. This great richness floristic observed can be justified by the diversity of the inventoried ecological niches. Indeed, in this conservation area, we find cultivated areas with their ruderal species; fallow land rich in pioneer species; swamps and gallery forests, which shelter species particularly adapted to life in contact with water. It is also worth noting that this area in contact with the Taï National Park has been identified as a centre of gradients of floristic diversity in Côte d'Ivoire (Kouamé et al., 2004).

The dominance of the Fabaceae, Rubiaceae, Euphorbiaceae is not a characteristic peculiar to the biodiversity conservation area of the Soubré hydroelectric dam. It is this same floristic procession that is observed in most Ivorian forests according to several studies (Nusbaumer et al., 2005; N'Da et al., 2008; Kouamé et al., 2010; Vroh, 2013). These families, generally of the GuineanCongolese type, and developing in dense humid forests (Kouamé, 2009), on the one hand justify the high proportion of species from the Guinean-Congolese region (GC). On the other hand, the dominance of species from the Guineo-Congolese region (GC) is proof that this area does indeed belong to the GuineoCongolese region (Tiokeng et al., 2015). However, their proportion is still low compared to the $80 \%$ to $90 \%$ endemism rate that the flora of this phytogeographic region should have (Solefack et al., 2018). On the basis of the dominance of this category of species and their low proportion, we could evoke a beginning of vegetation recovery (Vroh, 2013). It is this reconstitution of vegetation that is reflected, on the one hand, by the preponderance of smalldiameter individuals that are regeneration individuals and, on the other hand, by the high frequency of pioneer species such as Alchornea cordifolia, Rauvolphia vomitoria, Ceiba pentandra and Chromolaena odorata. The abundance of pioneer species during the initial phases of reconstitution of vegetation destroyed in favour of anthropogenic activities in the Ivorian forest areas has already been observed by Vroh (2013).

The biodiversity conservation area is a refuge for species with a special status in that it abounds with a concentration of rare and/or endangered species, as well as endemic species. This characteristic of the conservation area gives it the first High Conservation Value (HCV 1) which requires a concentration of biological diversity including endemic species and rare, threatened or endangered species of international, regional or national importance. As far as rare and/or threatened species are concerned, 6 of the $14(42.86 \%)$ threatened species of Ivorian flora were found in the biodiversity conservation area. These results confirm the importance of the area for the conservation of the endemic and threatened flora of this region. As for endemic species, the 3 categories reported by Alonso et al. (2005), namely West African endemic species, Ivorian endemic species and "Sassandrian" species, can be found there. The latter characterise the vegetation between Sassandra and Cavally river. The presence of these endemic species bears witness to a conserved environment (Adou Yao, 2005) and is a sign of great biodiversity. Consequently, their distribution is frequently used to indicate biodiversity hotspots (Myers, 2000). Their strong presence in the conservation area is due to certain biotopes, such as formations on islands that escaped human activities due to their difficult access before the construction of the dam. Also, there are some relics of secondary forests spared by the populations that would have sheltered these species during the establishment of the cocoa plantations.

With regard to the use of species, the populations identify several species in different fields. The availability of these species in the biodiversity conservation area confers the area the High Conservation Value of category 5 (HCV 5). Some species are used in several fields. This makes them species of high importance value for the population. The encounter of multiple useful species in a region reveals the high level of traditional knowledge of the populations (Makumbelo et al., 2008). The use of a woody species in different fields 
is based on the complex biological organisation of this group of plants (Ozenda, 2007). Indeed, they produce various organs that are used in response to the multiple needs of rural communities. For these communities, plant species constitute a means of subsistence in view of the social and economic values attached to each of them (Neffati et al., 2016). Ecosystem services are now recognised as essential for people's well-being (MEA, 2005). Among the ecosystem services provided by the area, the supply of medicinal plants is one of the most valuable resources for the vast majority of riparian populations. Indeed, the traditional use of medicinal plants for first aid forms the basis of curative medicine for lowincome populations (Dounias et al., 2000). More than $80 \%$ of the rural population in Africa use them for their health care (Fokunang et al., 2011).

As regards the organs used in the practice of traditional medicine, the leaves are the most commonly used. The authors Ambé et al. (2015) also showed that leaves are the plant organs most used in traditional medicine in the treatment of various diseases. The frequent use of leaves is justified by the abundance of chemical groups they contain, as they are known as the site of synthesis of secondary plant metabolites (Mangambu et al., 2014). For the ethnic groups living in the biodiversity conservation area, food plants would contribute to food security and also to poverty reduction. This assertion has already been mentioned by Loubelo (2012). Among the plant organs sought in food needs, fruits are the most frequently cited. These results corroborate those of Abdou et al. (2020). The high consumption of wild fruits has been abundantly noted in the literature in Côte d'Ivoire (Betti et al., 2016), and elsewhere in Africa (Koné et al., 2018). Indeed, they are sought after for their tasty and aromatic pulp and can make a significant contribution to the balance of the diets of rural populations (Makalao et al., 2015). The use of plant stems for handicrafts, timber and others is a matter for the local populations' know-how in the control of the resources of their natural environment. These observations have also been made by several authors including Kouakou et al. (2020) who identified 39 species and 55 others used successively in the construction and manufacture of domestic objects by the Koulango and Lobi populations of the eastern periphery of Comoé National Park. The most commonly used species would be selected taking into account several criteria including strength, durability, resistance to termites and wood-boring insects, wood configuration and above all workability (Gormo, and Nizesete, 2013).

The rarity of the most important plants for the populations would be due to their high demand and the way they are harvested, most of which is based on debarking, cutting roots and stems. These modes of harvesting coupled with the intensity of harvesting would make them highly vulnerable (Makumbelo et al., 2008). In fact, there is a clear relationship between the part of the plant exploited and species regeneration on the one hand, and on the other hand, the method and intensity of harvesting on species regeneration (Dossou et al., 2012). Thus, it is important to raise awareness of rational techniques for harvesting plant organs so as not to undermine the possibility of benefiting sustainably from the services of these high-value plants.

Authors recognise that the importance value of a plant can explain its preservation and the attribution of a special place in the land management system (Guillemette, 2014). This would prevent the loss of these resources, which would lead to a weakening of local potential and the ability of dependent communities to earn income from them (Luck et al., 2009). Thus, taking this information into account, high-value species of importance should be considered as a priority in the further development of the area in order to contribute to the well-being of the population in a sustainable manner.

\section{Conclusion}

The study carried out in the biodiversity conservation area of the Soubre hydroelectric dam has made it possible to take stock of the available information and to highlight some characteristics of the vegetation. The study showed that the flora is rich in 346 species divided into 262 genera and 92 families. Among these species, 50 have a special status due to their endemism, vulnerability or rarity. 
The floristic richness and the rarity or vulnerability of certain species clearly illustrate the specific nature of the biodiversity of the conservation area, which gives it the High Conservation Value of category 1 (HVC 1). Among these species, 84 are cited by the populations as useful plants, i.e. $24.27 \%$. The main categories of use are, in order of importance, medicinal use, food use, handicrafted use, timber and services. The organs used in these fields are mainly leaves in traditional medicine, fruits for food needs and stems in handicrafts, timber and energy wood. Of all the useful plants, thirteen (13) are of major importance for the populations with importance value at least 50\%. Of these, six (6) are still poorly available such as Ricinodendron heudelotii, Carpolobia lutea G. Don. The capacity of the area to serve as a refuge for useful species gives it the High Conservation Value of category 5 (HVC 5). The results of this study will enable the implementation of appropriate management to ensure the preservation and/or improvement of the HVC present in the area.

\section{COMPETING INTERESTS}

The authors state that they have no competitive interests.

\section{AUTHORS' CONTRIBUTIONS}

YJCK is the principal investigator of this work and has been involved in all phases of the work. AC and KBK contributed to the data collection in the biodiversity conservation area and to the writing of the article. M-ST, DO and KEN contributed with their readings to the improvement and validation of the manuscript.

\section{ACKNOWLEDGEMENTS}

The authors of this article would like to express their gratitude to BNETD who facilitated the field work and to CI-ENERGIE, owner of the study area. We do not forget the local populations who kindly submitted to the questionnaires during the ethnobotanical study. The authors would also like to thank the referees for their constructive remarks which have helped to improve the document.

\section{REFERENCES}

Abdou MKA, Rabiou H, Abdou L, Mamadou MI, Mahamane A. 2020. Connaissances ethnobotaniques et importance socioculturelle de Balanites aegyptiaca (L.) Del. dans le Centre-Est du Niger. Afrique SCIENCE, 16(4) : 239 252.

Adou Yao CY. 2005. Pratiques paysannes et dynamiques de la biodiversité dans la forêt classée de Monogaga (Côte d'Ivoire), Thèse de Doctorat unique, département Hommes Natures Sociétés, MNHN, Paris, France. 248p.

Adou Yao CY, N'Guessan EK. 2005. Diversité botanique dans le sud du parc national de Taï, Côte d'Ivoire. Afrique SCIENCE, 01(2) : 295 - 313.

Aké-Assi L. 2001. Flore de Côte d'Ivoire 1, catalogue systématique, biogéographie et écologie. Conservatoire et Jardin Botaniques, Genève, Suisse. 396pp.

Aké-Assi L. 1998. Impact de l'exploitation forestière et du développement agricole sur la conservation de la biodiversité biologique en Côte d'Ivoire. Le Flambloyant, 46: 20 - 21.

Aké-Assi L. 2002. Flore de la Côte d'Ivoire 2, Catalogue Systématique, Biogéographie et Écologie. Conservatoire et Jardin Botanique : Genève, Suisse ; 441p.

Alonso LE, Lauginie F, Rondeau G. 2005. Une Évaluation Biologique de deux Forêts Classées du Sud-Ouest de la Côte d'Ivoire. Conservation International : Washington D.C, USA ; $91-100$.

Ambe AS, Ouattara D, Tiebre MS, Vroh BTA, Zirihi GN, N'guessan KE. 2015. Diversité des plantes médicinales utilisées dans le traitement traditionnel de la diarrhée sur les marchés d'Abidjan (Côte d'Ivoire). Journal of Animal \& Plant Sciences, 26(2): 4081-4096.

Betti JL, Ngankoué CM, Dibong SD, Singa AE. 2016. Etude ethnobotanique des plantes alimentaires spontanées vendues dans les marchés de Yaoundé, Cameroun. International Journal of Biological and Chemical Sciences, 10(4): 1678-1693. DOI: 10.4314/ijbcs.v10i4.19

Bouko SB, Sinsin B, Soulé GB. 2007. Effets de la dynamique d'occupation du sol sur la 
structure et la diversité des forêts claires et savanes du Bénin. Tropicultura, 25(4) : $221-227$.

Dossou ME, Houessou GL, Lougbégnon OT, Tenté AHB, Codjia JTC. 2012. Ethnobotanical study of ligneous species in Agonvè swampy forest and surrounding area in Benin. Tropicultura, 30(1) : 41 - 48.

Dounias E, Rodrigue W, Petit C. 2000. Revue de la littérature ethnobotanique pour l'Afrique centrale et l'Afrique de l'ouest. Bulletin du Réseau Africain d'Ethnobotanique, 2 : 5-117.

FAO-REDD+. 2015. Données forestières de base pour la REDD+ en en Côte d'Ivoire : cartographie de la dynamique forestière de 1986 à 2015, rapport d'étude. 32pp.

Fokunang CN, Ndikum V, Tabi OY, Jiofack RB, Ngameni B, Guedje NM, TembeFokunang EA, Tomkins P, Barkwan S, Kechia F, Asongalem E, Ngoupayou J, Torimiro NJ, Gonsu KH, Sielinou V, Ngadjui BT, Angwafor III F, Nkongmeneck A, Abena OM, Ngogang J, Asonganyi T, Colizzi V, Lohoue J, Kamsu-Kom. 2011. Traditional medicine: past, present and future research and development prospects and integration in the national health system of Cameroon. African Journal of Traditional, Alternative and Complementary Medecine, 8(3) : 284 295.

Géhu JM. Géhu J. 1980. Essai d'objection de l'évaluation biologique des milieux naturels. Exemples littoraux. In Géhu J.M. (Eds.). Séminaire de Phytosociologie Appliquée, Amicale Francophone de Phytociologie, Metz, France. pp. 75-94.

Gormo J, Nizesete BD. 2013. Des végétaux et leurs usages chez les peuples du NordCameroun : sélection et mode d'emploi du $\mathrm{XIX}^{\mathrm{e}}$ au $\mathrm{XX}^{\mathrm{e}}$ siècle. História, Ciências, Saúde-Manguinhos, 20(2) : 587 - 607.

Guillemette E. 2014. Caractérisation et suivi des attributs multiressources de la Forêt habitée du Massif dans un contexte d'aménagement durable. Rapport de Maîtrise en science forestière, Université de Laval, Québec, Canada. 65 p.
Konan KE. 2008. Conservation de la diversité végétale et activités humaines dans les aires protégées du sud forestier ivoirien : l'exemple du Parc National d'Azagny. Thèse Unique Université d'AbidjanCocody, Côte d'Ivoire. 210p.

Kone HS, Kone KY, Akaki KD, Soro D, Elleingang FE, Assidjo NE. 2018. Caractérisation biochimique de la pulpe des fruits du prunier noir (vitex doniana) de la Côte d'Ivoire. European Scientific Journal, 14(3): 252-270. DOI: https://doi.org/10.19044/esj.2018.v $14 n 3 p 252$

Kouakou YB, Kougbo MD, Konan AS, Malan DF, Bakayoko A. 2020. Usages traditionnels et disponibilite des plantes exploitees dans l'artisanat chez les populations koulango et lobi de la peripherie est du parc national de la comoe, Côte d'Ivoire. European Scientific Journal, 16(9): 295-320. DOI: https://doi.org/10.19044/esj.2020.v 16n9p295

Kouamé D, Adou Yao CY, Nandjui A, N'Guessan EK. 2010. Le rôle de l'éléphant dans la germination des graines de Irvingia gabonensis (Irvingiaceae), Balanites wilsoniana (Balanitaceae), Parinari excelsa (Chrysobalanaceae) et Sacoglottis gabonensis (Humiriaceae) en forêt tropicale: cas du Parc National d'Azagni. International Journal of Biological and Chemical Sciences, 4(5) : 1442-1454.

DOI: 10.4314/ijbcs.v4i5.65562

Kouamé D. 2009. Rôle des animaux frugivores dans la régénération et la conservation des forêts : cas de l'éléphant (Loxodonta africanacyclotis Matschié, 1900) dans le Parc National d'Azagny (Sud-est de la Côte d'Ivoire). Thèse de Doctorat, Université de Cocody-Abidjan, Côte d'Ivoire. 215p.

Kouamé NF, Kouadio KE, Kouassi K, Poorter L. 2004. Floristic diversity of closed forests in Côte d'Ivoire. In Biodiversity of West African forests: an Ecological Atlas of Woody Plant Species, Poorter L, Bongers F, Kouame FN. Hawthorne W. (Eds). Colophon : Wageningen; 53-60. 
Lanly JP. 1969. Régression de la forêt dense en Côte-d'Ivoire. Bois et Forêts des Tropiques, 127(127) : 45 - 59.

Loubelo E. 2012. Impact des produits forestiers non ligneux (PFNL) sur l'économie des ménages et la sécurité alimentaire : cas de la République du Congo. Thèse de doctorat, Université Renne 2, Renne, France. 310 p.

Luck GW, Chan KM, Fay JP. 2009. Protecting ecosystem services and biodiversity in the world's watersheds. Conservation Letters, 2(4): 179-188. DOI: 10.1111/j.1755-263X.2009.00064.x

Makalao MM, Savadogo A, Zongo C, Traore AS. 2015. Composition nutritionnelle de 10 fruits sauvages consommés dans trois départements du Tchad. International Journal of Biological and Chemical Sciences, 9(5): 2385-2400. DOI: $10.4314 /$ ijbcs.v9i5.11

Makumbelo E, Lukoki L, Paulus JJSJ, Luyindula N. 2008. Stratégie de valorisation des espèces ressources des produits non ligneux de la savane des environs de Kinshasa : II. Enquête ethnobotanique (aspects médicinaux). Tropicultura, 26(3) : 129134.

Mangambu MDD, Mushagalusa KF, Kadima NJ. 2014. Contribution à l'étude photochimique de quelques plantes médicinales antidiabétiques de la ville de Bukavu et ses environs (Sud-Kivu, RD Congo). Journal of Applied Biosciences, 75 :

6211-6220.

DOI: $10.4314 /$ jab.v75i1.7

MEA. 2005. Ecosystems and Human Wellbeing. Island Press: Washington DC, USA; 917p.

Myers N, Mittermeier RA, Mittermeier CG, Da Fonseca GAB, Kent J. 2000. Biodiversity hotspots for conservation priorities. Nature, 403: 853-858. DOI: https://doi.org/10.1038/35002501

N'Da D, Adou Yao CY, N'guessan KE, Kone M, Sagne YC. 2008. Analyse de la diversité floristique du parc national de la Marahoué, Centre-Ouest de la Côte d'Ivoire. Afrique SCIENCE, 4(3) : 552 579 .
Neffati M, Sghaier M, Labbene Y. 2016. Analyse de la vulnérabilité des écosystèmes et des moyens de subsistance Livelihoods) des populations au changement climatique en zones arides et désertiques de la région MENA. Rapport principal, Centre national de documentation, Rabat, Maroc. 202 pp.

Nusbaumer L, Gautier L, Chatelain C, Spichiger R. 2005. Structure et composition floristique de la Forêt Classée du Scio (Côte d'Ivoire), Etude descriptive et comparative. Candollea, 60(2) : $393-443$.

Ozenda P. 2007. Les Végétaux : Organisation et Diversité Biologique. Ed. Dunod: Grenoble, France ; 528p.

Poorter L, Bongers F, Kouamé FN, Hawthorne W. D. 2004. Biodiversity of West African Forests: An Ecological Atlas of Woody Plant Species. CABI Publishing: Netherland, Pays-Bas; 521p.

Schneiders A, Van Daele T, Van Landuyt W, Van Reeth W. 2012. Biodiversity and ecosystem services: Complementary approaches for ecosystem management? Ecological Indicators, 21: 123-133. DOI: https://doi.org/10.1016/j.ecolind.2011.06 .021

Solefack MCM, Temgoua LF, Fedoung E, Djouba RZ. 2018. Végétation et spectres fonctionnels de la galerie forestière de Koupa Matapit (Ouest-Cameroun). GeoEco-Trop, 42(1) : 147 - 158.

Tiokeng B, Mapongmetsem P, Nguetsop VF, Tacham WN. 2015. Biodiversité floristique et régénération naturelle sur les Hautes Terre de Lebialem (Ouest Cameroun). International Journal of Biological and Chemical Sciences, 9(1): 56 - 68. DOI: 10.4314/ijbcs.v9i1.6

UICN. 2018. IUCN Red List of Threatened Species. [Online] Available: http://www.iucnredlist .org (Avril 2018)

Vroh BTA. 2013. Evaluation de la dynamique de la végétation dans les zones agricoles d'Azaguié (Sud-Est, Côte d'Ivoire). Thèse de Doctorat, Université Félix Houphouët Boigny, Abidjan, Côte d'Ivoire, 208p. 